\title{
Large wildland fires and extreme temperatures in Sardinia (Italy)
}

\author{
Adrian Cardil ${ }^{(1)}$, Michele Salis ${ }^{(2-3)}$, Donatella Spano ${ }^{(2-3)}$, \\ Giuseppe Delogu ${ }^{(4)}$, Domingo Molina Terrén ${ }^{(1)}$
}

\begin{abstract}
Heat-wave events are commonly recognized as adverse impacts on agriculture, forests, and economic activities. Several studies showed that future climate changes in the western Mediterranean Basin will lead to an increase in extreme weather events, mainly in the summer season. For this reason, it is crucial to improve our knowledge on the effects of extreme temperature events on wildland fire activity. This work analyses the relation between high temperature days (air temperature higher than $25^{\circ} \mathrm{C}$ at $850 \mathrm{hPa}$ ) and large wildland fires in Sardinia (Italy) during the period 1991-2009. Our results showed that the influence of high temperature days on large wildland fires was remarkable. Neither the number of fires nor the area burned decreased under high temperature days, although a decrease of both parameters was observed on other days. Additionally, the average size of fires, the probability of large fire occurrence, the daily area burned and daily number of fires were higher on high temperature days.
\end{abstract}

Keywords: Wildfires, Temperature, Extreme, Weather

\section{Introduction}

Heat-wave days cause adverse impacts on forests and economic activities (Kuglitsch et al. 2010, Mills 2005, Trigo et al. 2006). In addition, they play a key role on human health and death (García-Herrera et al $2005)$. The last 13 years $(2000-2012)$ were characterized by frequent heat waves, which often triggered the occurrence of large wildfires (Barriopedro et al. 2011, Mills 2005 , CNFDB 2013, Trigo et al. 2006) in the Euro-Mediterranean region (Italy and Greece, 2007; Portugal, 2003 and 2005; Spain, 2006 and 2009) and overall the world (Australia, 1983 and 2009; Canada, 2004; Russia, 2010; USA, 2000, 2006 and 2007). In hot days, usually associated with very low fine dead fuel moisture content, the ignition probability is higher and wildland fire behavior could be extreme (e.g., increasing flame length, rate of spread, crown fire activity, and spotting activity). Therefore, fires can burn rapidly and intensely, and originate large and severe wildland fires difficult to extinguish, exceeding the fire-fighting capabilities (Molina et al. 2010, Salis et al. 2012b).

Climate change projections for the western Mediterranean Basin show a greater variability in weather conditions and an increase in extreme weather events, mainly in the summer season, when longer and more frequent heat waves are expected to happen (Arca et al. 2012, Barriopedro et al. 2011, Moriondo et al. 2006, Regato 2008). This will result in an increase in wildfire activity (Arca et al. 2012, Flannigan et al. 2000, IPCC 2007, Riaño et al. 2007). For this reason, it is crucial to investigate the effects of temperature extreme events on fire activity and large wildland fires.

We chose the island of Sardinia (Italy) as case study for our analysis. Sardinia is a fireprone area experiencing thousands of wildfires every year (Arca et al. 2007, Pereira et al. 2011, Salis et al. 2012a); some of them

(1) School of Agrifood and Forestry Science and Engineering, University of Lleida, av.da Rovira Roure 191, E-25198 Lleida (Spain); (2) Department of Science for Nature and Environmental Resources (DIPNET), University of Sassari (Italy); (3) Euro Mediterranean Center on Climate Change (CMCC), IAFENT Division, Sassari (Italy); (4) Corpo Forestale e di Vigilanza Ambientale, Regione Sardegna, Cagliari (Italy)

@ Adrian Cardil (adriancardil@gmail.com)

Received: Jul 27, 2013 - Accepted: Oct 21, 2013

Citation: Cardil A, Salis M, Spano D, Delogu G, Molina Terrén D, 2014. Large wildland fires and extreme temperatures in Sardinia (Italy). iForest 7: 162-169 [online 2014-02-14] URL: http://www.sisef.it/iforest/contents/?id=ifor1090-007

Communicated by: Raffaele Lafortezza were very large fires as Bonorva's fire $(23$ July 2009 - 9500 ha burned) and Nuoro's fire (23-25 July 2007 - 9150 ha burned). Wildland fires larger than 100 ha (LWF) represent a small percentage of the total number of occurring fires but account for most of the area burned and cause the most of damage (Ganteaume \& Jappiot 2012, Salis et al. 2012a, Stocks et al. 2003) with more severe fire behavior (Molina et al. 2010).

In this work, we assessed the historical relationship between high temperature days (HTD) and LWF in Sardinia, Italy. High temperature days were defined as those days in which the $850 \mathrm{hPa}$ air temperature was equal or higher than $25^{\circ} \mathrm{C}$ in at least twothirds of north and south Sardinia. The 850 $\mathrm{hPa}$ pressure level is representative of the Earth surface and has the potential to identify unusually severe fire weather events (Mills 2005). It is generally used by Forest Services to analyze past fire weather and forecast daily potential fire occurrence and behavior (García-Ortega et al. 2011, Trigo et al. 2006). We analyzed the historical trends of LWF and HTD in north and south Sardinia from 1991 to 2009 and their relationships in terms of fire number, burned area, and mean fire size. We also assessed the probability of having LWFs in HTD and the role of other factors (wind speed and number of ignitions) influencing LWF occurrence and burned area in HTD. Finally, we analyzed the differences between north and south Sardinia considering fire number, burned area and mean fire size.

\section{Methods}

\section{Study area}

Sardinia is a large island in the Mediterranean Sea (Fig. 1 - $24235 \mathrm{~km}^{2}$ ) located between $38^{\circ} 51^{\prime} \mathrm{N}$ and $41^{\circ} 15^{\prime} \mathrm{N}$ latitude and $8^{\circ} 8^{\prime} \mathrm{E}$ and $9^{\circ} 50^{\prime} \mathrm{E}$ longitude. The territory includes eight administrative provinces and a population of about 1.7 million inhabitants. In this work, we identified two reference areas (Fig. 1): northern Sardinia (including Sassari, Olbia-Tempo, and Nuoro provinces) and southern Sardinia (including Oristano, Ogliastra, Cagliari, Medio-Campidano, and Carbonia-Iglesias provinces). In a preliminary analysis of fire size data (larger fires in the northern part) and the number of high temperature days (higher number in the southern part) showed a marked difference between north and south Sardinia; for these reasons, the island was divided in two parts.

Overall, the island has a complex topography with hills and low mountains (Ricotta et al. 2012). The average elevation of the island is $338 \mathrm{~m}$ a.s.l. and the highest point is Punta la Marmora with 1834 m a.s.l. in the center of the island.

The flora includes 2407 taxonomic species, 


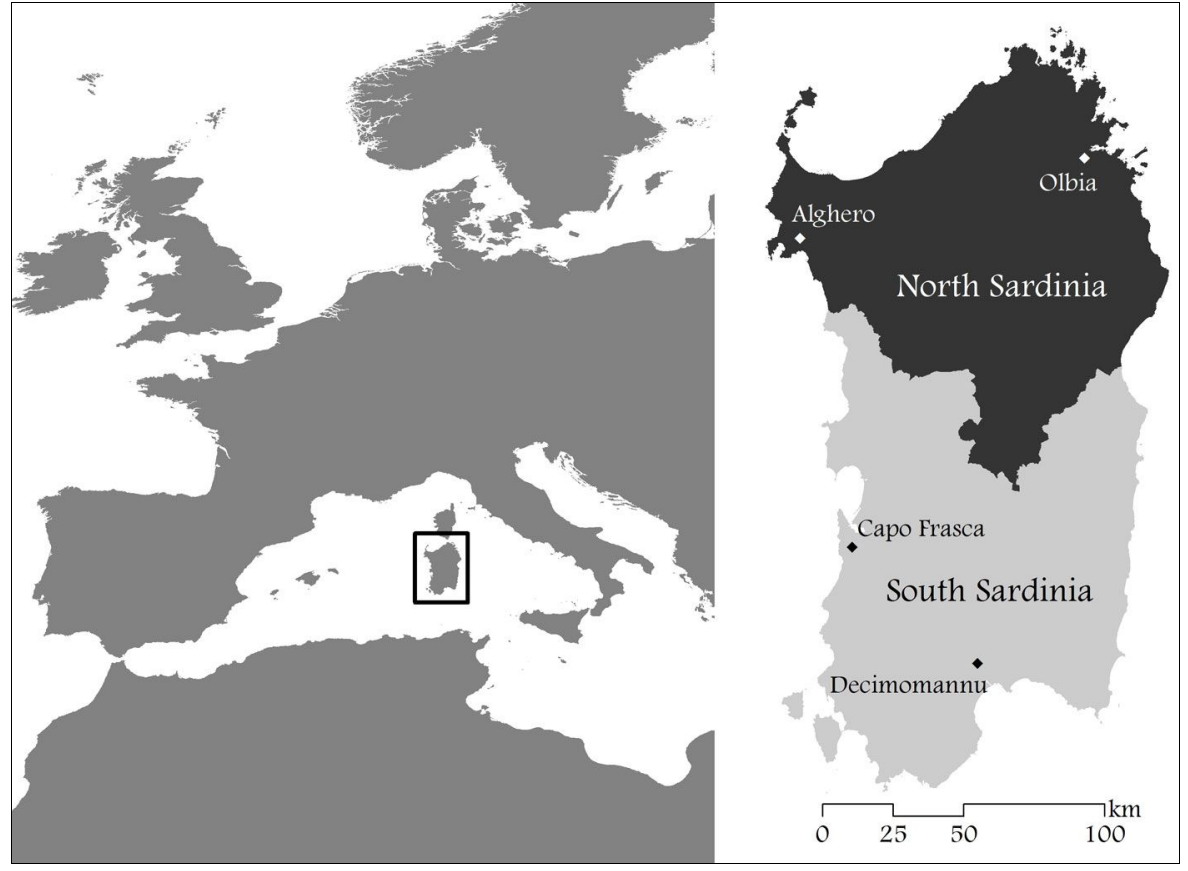

Fig. 1 - Geographic location of Sardinia (Italy) and northern and southern parts of the island.

of which $10 \%$ are endemic (De Angelis et al. 2012). Large areas are covered by scrub and/ or herbaceous vegetation associations (approx. $35 \%$ in the north and $36 \%$ in the south), comprised primarily of Pistacia lentiscus L., Arbutus unedo L., Erica arborea L., Myrtus communis L., Olea europea L., Phyllirea spp., Juniperus spp. and Cistus spp. (Salis et al. 2012a). Woodlands and forest area is approximately $23 \%$ in the north and $17 \%$ in the south of Sardinia, with the main tree species being Quercus ilex L., $Q$. suber L., $Q$. pubescens Willd., and $Q$. congesta Presl. Pine plantations with Pinus pinea $\mathrm{L}$. and $P$. halepensis Mill. only cover $3 \%$ of the island and are mainly concentrated along the coast (Salis et al. 2012a). Pastures and agricultural lands represent about 36\% in the north and $39 \%$ in the south, while the urban areas cover $3 \%$ of the island.

The climate is classified as Mediterranean, with dry hot summers and an important water deficit from May to September (Chessa \& Delitala 1997). The mean annual temperature ranges from $17.8{ }^{\circ} \mathrm{C}$ in the southern coast to $12.8{ }^{\circ} \mathrm{C}$ in the mountainous areas Maximum temperature peaks are higher than $30.8^{\circ} \mathrm{C}$ during the summer season. Average annual rainfall is $1300 \mathrm{~mm}$ in the mountains, but slightly less than $500 \mathrm{~mm}$ in the coast, and most of the annual rainfall occurs in fall and winter.

\section{Fire data}

We used the historical fire data records from the Sardinian Forest Service (CFVA Corpo Forestale e di Vigilanza Ambientale) from 1991 to 2009 in north and south Sar dinia. The CFVA database has an entry for each wildfire ignition and provides information on date, municipality and location of the ignition, and area burned. On average, in the last years (1995-2009) Sardinia experienced approximately 2500 fires per year and about 17000 ha burned per year. Wildfires are typically concentrated from June to September, with the maximum in July for both ignitions and area burned (Salis et al. 2012a). Therefore, this work was focused on the June-September period. Similar to elsewhere in Euro-Mediterranean ecosystems (Molina et al. 2010), a few large wildland fires account for most of the burned area (Salis et al. 2012a). For instance, in Sardinia fires larger than 100 ha accounted approximately for $60 \%$ of the total area burned. In the studied period, fires larger than 100 hectares were 806 and the area burned about 290000 ha. We analyzed large wildland fires considering three different size classes: wildland fires larger than 100 ha $\left(\mathrm{LWF}_{100}\right), 500$ ha $(\mathrm{LW}-$ $\left.\mathrm{F}_{500}\right)$, and 1000 ha $\left(\mathrm{LWF}_{1000}\right)$.

\section{High temperature days (HTD)}

Re-analysis data from the National Centers for Environmental Prediction (Kalnay et al. 1996) were used to characterize the high temperature days on a synoptic scale. Daily air temperature maps at $850 \mathrm{hPa}$ pressure level were analyzed to assess the influence of high temperatures on LWF for both north and south Sardinia from 1991 to 2009 . We defined high temperature days when the 850 $\mathrm{hPa}$ air temperature was equal or higher than $25^{\circ} \mathrm{C}$ at 00:00 UTC in at least two-thirds of both parts of Sardinia. Reversely, we defined as non-HTD those days characterized by 850 $\mathrm{hPa}$ temperature lower than $25^{\circ} \mathrm{C}$ at $00 \mathrm{Z}$ in the period June-September. The $850 \mathrm{hPa}$ air temperature was chosen as reference for several reasons. First, it is generally used by Forest Services to analyze past fire weather and to forecast daily potential fire occurrence and behavior (García-Ortega et al. 2011, Trigo et al. 2006). Second, it is sufficiently close to the surface to be representative of it, while some of the problems that affect near surface reanalysis variables do not occur (Ogi et al. 2005, Trigo et al. 2005, 2006). Third, it provides a regional coverage of air temperature. A temperature equal or higher than $25^{\circ} \mathrm{C}$ at $850 \mathrm{hPa}$ is commonly associated to heat waves (Montserrat 1998) and this condition is responsible of high temperatures at ground level in the territory, as occurred in Portugal in the summer of 2003 (Trigo et al. 2006) or in Russia (2010). Furthermore, we analyzed duration and frequency of HTD, and we used HTD as a proxy for the potential occurrence of fires larger than 100 ha.

\section{Statistical analysis}

We analyzed the number of HTD, LWF number and area burned for northern and southern parts of Sardinia using the ANOVA analysis and considering the normalized values of: (1) annual area burned by LWF for $1 \cdot 10^{6}$ ha; and (2) annual number of LWF for $1 \cdot 10^{6}$ ha.

We analyzed the trends of number of HTD, LWF number and area burned and the differences in LWF number, LWF area burned and LWF size under HTD and non-HTD.

To investigate the relationship between HTD and large fires, we defined the following indicators: (1) number of HTD with at least one LWF with respect to the total HTD (\%); (2) normalized LWF average number per HTD with LWF; (3) normalized LWF average area burned per HTD with LWF; and (4) area burned by LWF under HTD with respect to the total area burned by LWF (\%). To assess significant differences between HTD and other days, we calculated the same indicators considering non-HTD. The number of days classified as HTD or nonHTD was calculated in the June-September time frame because the HTD were concentrated in these months, and about all LWF were observed in those four months (Salis et al. 2012a, Trigo et al. 2006).

We also evaluated the influences of some explanatory variables on LWF. First, we calculated the number of fire ignitions for each HTD and the differences in ignition number considering days with and without LWF to understand how much the number of ignitions was associated to the occurrence of LWF in these extreme days. Second, we collected daily average wind speed data from several weather stations of the island to eva- 
Tab. 1 - Normalized average annual large wildland fire (LWF) number, normalized average LWF area burned, average LWF size and ave rage annual number of high temperature days (HTD) and standard error in north and south Sardinia, from 1991 to 2009 . The trend analysis for all variables in the time frame is also reported. $(+)$ : significantly increased at $\mathrm{P}<0.05$; (-): significantly decreased at $\mathrm{P}<0.05$; (ns): not si gnificant. Values in parenthesis are the P statistics.

\begin{tabular}{|c|c|c|c|c|c|c|c|c|c|}
\hline \multirow[b]{2}{*}{ Indicator } & \multirow[b]{2}{*}{$\begin{array}{l}\text { LWF } \\
\text { class }\end{array}$} & \multicolumn{4}{|c|}{ North } & \multicolumn{4}{|c|}{ South } \\
\hline & & $\begin{array}{c}\text { Normalized } \\
\text { average an- } \\
\text { nual LWF } \\
\text { number }\end{array}$ & $\begin{array}{l}\text { Normalized } \\
\text { average annual } \\
\text { LWF area } \\
\text { burned (ha) }\end{array}$ & $\begin{array}{c}\text { Average } \\
\text { LWF size } \\
\text { (ha) }\end{array}$ & $\begin{array}{c}\text { Average } \\
\text { annual HTD } \\
\text { number }\end{array}$ & $\begin{array}{c}\text { Normalized } \\
\text { average an- } \\
\text { nual LWF } \\
\text { number }\end{array}$ & $\begin{array}{l}\text { Normalized } \\
\text { average annual } \\
\text { LWF area } \\
\text { burned (ha) }\end{array}$ & $\begin{array}{c}\text { Average } \\
\text { LWF size } \\
\text { (ha) }\end{array}$ & $\begin{array}{c}\text { Average } \\
\text { annual HTD } \\
\text { number }\end{array}$ \\
\hline Average & $\mathrm{LWF}_{100}$ & $16.2 \pm 3.8$ & $7553 \pm 1977$ & $465 \pm 54$ & 1.84 & $18.7 \pm 3.5$ & $5121 \pm 1093$ & $273 \pm 19$ & 3.73 \\
\hline \multirow[t]{2}{*}{ Value } & $\mathrm{LWF}_{500}$ & $3.1 \pm 0.9$ & $4811 \pm 1492$ & $1551 \pm 243$ & & $2.1 \pm 0.5$ & $1924 \pm 604$ & $927 \pm 135$ & \\
\hline & $\mathrm{LWF}_{1000}$ & $1.2 \pm 0.5$ & $3426 \pm 1224$ & $2790 \pm 541$ & & $0.42 \pm 0.2$ & $852 \pm 439$ & $2013 \pm 554$ & \\
\hline \multirow[t]{3}{*}{ Trends } & $\mathrm{LWF}_{100}$ & $-(0.035)$ & ns $(0.30)$ & $\mathrm{ns}$ & ns $(0.865)$ & $-(0.028)$ & ns $(0.08)$ & $\mathrm{ns}$ & ns (0.269) \\
\hline & $\mathrm{LWF}_{500}$ & ns $(0.17)$ & ns $(0.61)$ & ns & & $\mathrm{ns}(0.23)$ & $\mathrm{ns}(0.32)$ & ns & \\
\hline & $\mathrm{LWF}_{1000}$ & ns $(0.24)$ & ns $(0.84)$ & ns & & ns $(0.45)$ & ns $(0.43)$ & ns & \\
\hline
\end{tabular}

luate how wind velocity influenced HTD with or without LWF. We used four weather stations (Alghero and Olbia for north Sardinia, Capo Frasca and Decimomannu for south Sardinia). The weather data of these stations are available at http://www.tutiem po.net. Fire data were coupled with the closest weather station (among the above mentioned ones) to the fire ignition point.

\section{Results}

The normalized annual number of $\mathrm{LWF}_{100}$ in northern Sardinia was 16.2 fires per $10^{6}$ ha of wildlands and the normalized average annual area burned was 7553 ha per $10^{6}$ ha of wildlands, while in the south there were respectively $18.7 \mathrm{LWF}_{100}$ and 5121 ha burned. However, no significant differences between the two areas were found for both $\mathrm{LWF}_{100}$ number $(p$-value $=0.604)$ and area burned $(p$-value $=0.299)$. In north Sardinia, the total number of $\mathrm{LWF}_{100}$ calculated as five-year average decreased significantly along time from 38 to 10 fires ( $\mathrm{p}$-value $=0.035)$ and in south Sardinia from 44 to 14 fires (p-value $=0.028$ - Tab. 1, Fig. 2). The number of

Fig. 2 - Large wildland fire number $(100+$ ha $)$ in north and south Sardinia from 1991 to 2009 (June-September).
$\mathrm{LWF}_{100}$ under non-HTD also decreased in both northern and southern parts of Sardinia, but the number of $\mathrm{LWF}_{100}$ under HTD did not decrease in the study period (Tab. 2). In terms of burned area, we observed a decrease in the burned area under non-HTD in the two parts of the island for $\mathrm{LWF}_{100}$ (Tab. 2). Fig. 3 displays the LWF burned area in both north and south Sardinia.

Focusing on fires larger than 500 ha and 1000 ha, there were not significant differences between north and south Sardinia in both the normalized annual LWF number and the total area burned of $\mathrm{LWF}_{500}$ and $\mathrm{LWF}_{1000}$ (Tab. 1). Moreover, not significant trends were also observed for normalized annual LWF number and total area burned considering days with fires larger than 500 and 1000 ha. However, the number of $\mathrm{LWF}_{500}$ under non-HTD decreased significantly along time in both areas, and the normalized annual $\mathrm{LWF}_{500}$ burned area also decreased in south Sardinia in these conditions (Tab. 2). These variables were not analyzed in $\mathrm{LWF}_{1000}$ due to the insufficient amount of data to perform a statistical analysis.
The normalized annual average values of LWF number and burned area were significantly different between north and south Sardinia in $\mathrm{LWF}_{100}$ and $\mathrm{LWF}_{500}$ under nonHTD (Tab. 3). However, not significant differences were observed between the two parts of the island in LWF occurred under HTD.

Tab. 4 shows the relationships between HTD and non-HTD and LWF in both northern and southern Sardinia. There were differences between HTD and non-HTD in terms of LWF daily area burned and LWF daily number. In the north, the area burned by $\mathrm{LWF}_{100}$ under HTD equaled to $28.8 \%$ of the total area burned and the normalized average daily area burned per HTD with LWF in $L_{W F}$ category was significantly higher (2 503 ha day $^{-1}$ in $1 \cdot 10^{6}$ ha of wildlands) than in non-HTD (541 ha day ${ }^{-1}$ in $1 \cdot 10^{6}$ ha of wildlands - Tab. 4, Tab. 5). Similar results were obtained considering the average daily number of LWF in HTD and non-HTD with values of 2.7 ha day ${ }^{-1}$ vs. 1.4 ha day ${ }^{-1}$, respectively (Tab. 4 and Tab. 5). The average size of LWF in north Sardinia was signifi-

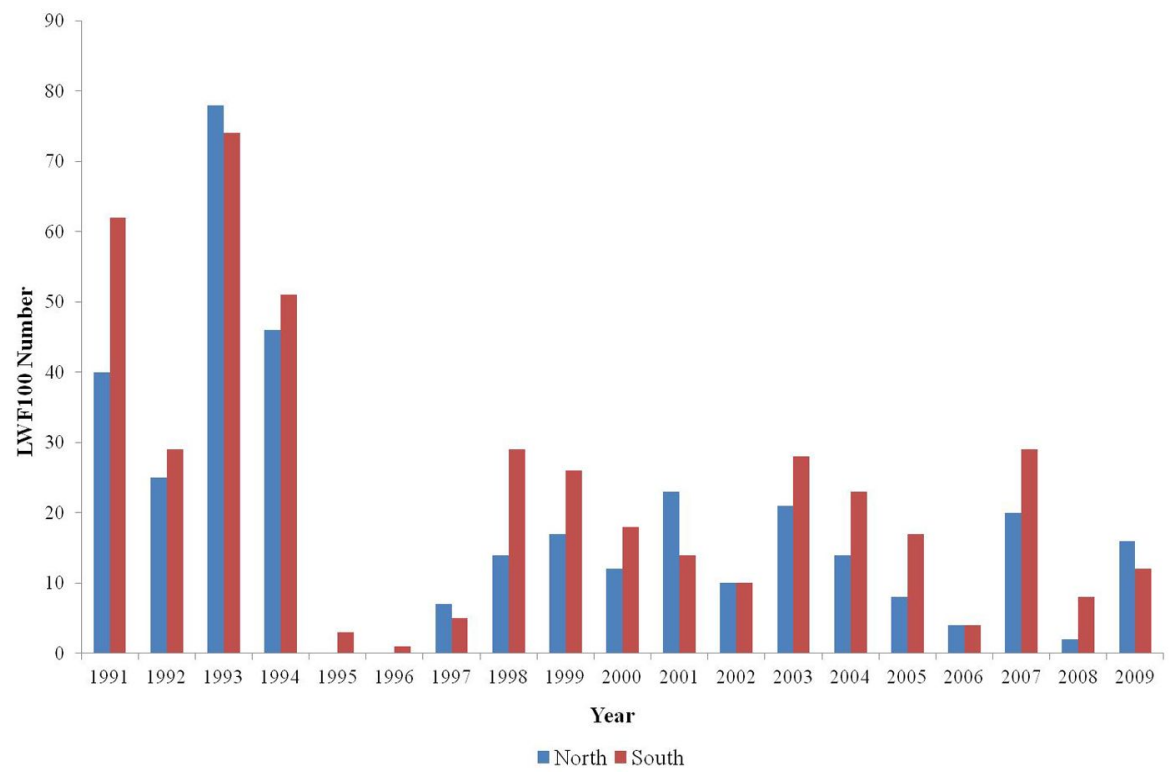


Tab. 2 - Trend analysis of normalized average annual large wildland fire (LWF) number, normalized average annual large wildland fire (LWF) area burned under high temperature days (HTD) and non-HTD in north and south Sardinia, from 1991 to 2009. (+): significantly in creased at $\mathrm{P}<0.05$; (-): significantly decreased at $\mathrm{P}<0.05$; (n.s.): not significant. Values in parenthesis are the $\mathrm{P}$ statistics.

\begin{tabular}{|c|c|c|c|c|c|}
\hline \multirow[b]{2}{*}{ Trends } & \multirow[b]{2}{*}{$\begin{array}{l}\mathbf{L W F} \\
\text { class }\end{array}$} & \multicolumn{2}{|c|}{ North } & \multicolumn{2}{|c|}{ South } \\
\hline & & $\begin{array}{l}\text { Normalized average } \\
\text { annual LWF number }\end{array}$ & $\begin{array}{c}\text { Normalized average } \\
\text { annual LWF area } \\
\text { burned (ha) }\end{array}$ & $\begin{array}{l}\text { Normalized average } \\
\text { annual LWF number }\end{array}$ & $\begin{array}{c}\text { Normalized average } \\
\text { annual LWF area } \\
\text { burned (ha) }\end{array}$ \\
\hline \multirow{3}{*}{ HTD } & $\mathrm{LWF}_{100}$ & n.s. $(0.662)$ & n.s. $(0.409)$ & n.s. $(0.844)$ & n.s. $(0.881)$ \\
\hline & $\mathrm{LWF}_{500}$ & n.s. $(0.709)$ & n.s. $(0.314)$ & n.s. $(0.217)$ & n.s. $(0.896)$ \\
\hline & $\mathrm{LWF}_{1000}$ & \multicolumn{4}{|c|}{ Insufficient values to test the trends } \\
\hline \multirow{3}{*}{ Non-HTD } & $\mathrm{LWF}_{100}$ & $-(0.018)$ & $-(0.049)$ & $-(0.017)$ & $-(0.028)$ \\
\hline & $\mathrm{LWF}_{500}$ & $-(0.027)$ & n.s. $(0.119)$ & $-(0.036)$ & $-(0.047)$ \\
\hline & $\mathrm{LWF}_{1000}$ & \multicolumn{4}{|c|}{ Insufficient values to test the trends } \\
\hline
\end{tabular}

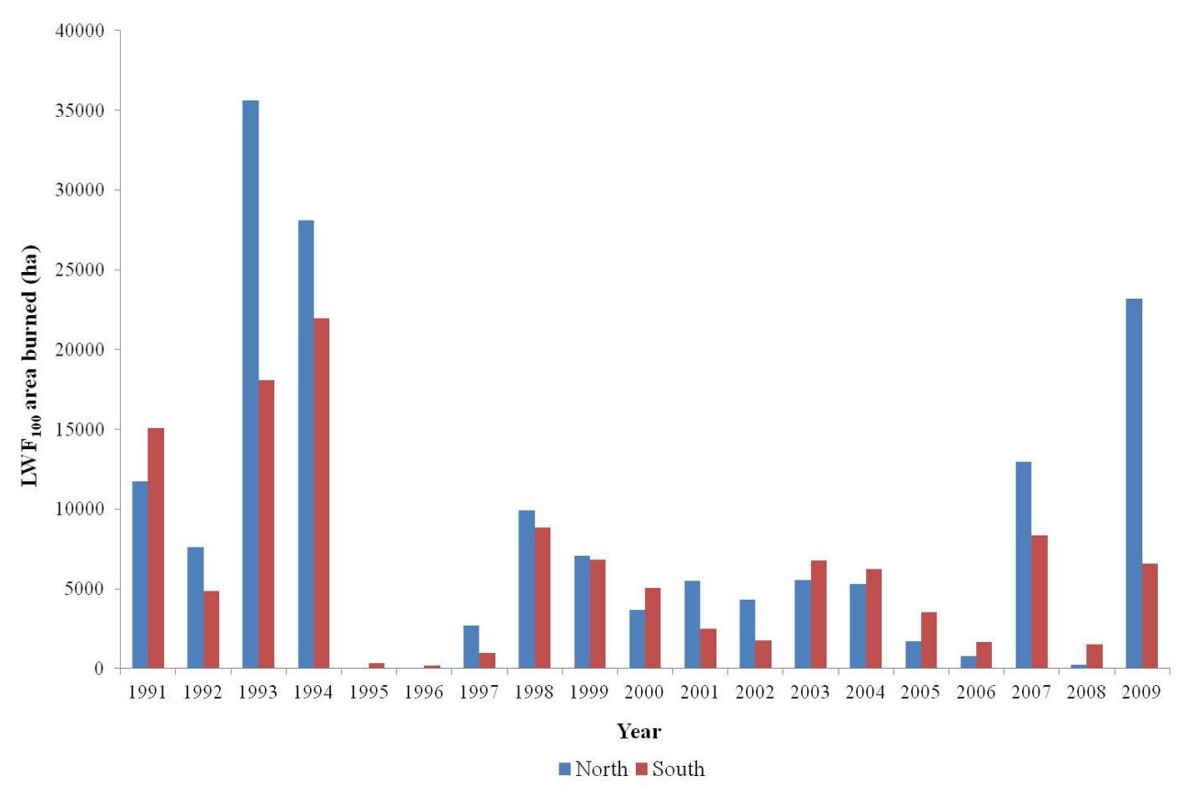

cantly different between HTD and non-HTD in $\mathrm{LWF}_{100}$ (944 vs. 396 ha, respectively). In the southern part, differences between HTD and non-HTD were also important, as shown in Tab. 4 and Tab. 5.

Considering the $\mathrm{LWF}_{500}$ and $\mathrm{LWF}_{1000}$, significant differences were observed between HTD and non-HTD in daily number of large fires, but not in relation to LWF daily burned area (Tab. 5) in north Sardinia. By contrast, in the southern part of the island, significant differences were found in LWF daily area burned in $\mathrm{LWF}_{500}$ and $\mathrm{LWF}_{1000}$, while in the case of the LWD daily number only LW$\mathrm{F}_{500}$ showed significant differences.

Our analysis highlighted that the annual
Fig. 3 - Large wildland area burned (100+ ha) in north and south Sardinia from 1991 to 2009 (June-September).

Tab. 3 - Comparison between north and south Sardinia in terms of normalized average annual LWF number and normalized average annual large wildland fires (LWF) area burned from 1991 to 2009. The values reported are P statistics.

\begin{tabular}{|c|c|c|c|c|c|c|c|}
\hline \multirow{2}{*}{ Indicator } & \multirow{2}{*}{$\begin{array}{l}\mathbf{L W F} \\
\text { class }\end{array}$} & \multicolumn{2}{|c|}{$\begin{array}{c}\text { Normalized average annual } \\
\text { LWF number }\end{array}$} & \multicolumn{2}{|c|}{$\begin{array}{l}\text { Normalized average annual } \\
\text { LWF area burned }\end{array}$} & \multicolumn{2}{|c|}{ Average LWF size } \\
\hline & & HTD & Non-HTD & HTD & Non-HTD & HTD & Non-HTD \\
\hline Comparison between & $\mathrm{LWF}_{100}$ & 0.097 & 0.032 & 0.136 & 0.002 & 0.186 & 0.001 \\
\hline north and south & $\mathrm{LWF}_{500}$ & 0.238 & 0.005 & 0.293 & 0.028 & 0.468 & 0.065 \\
\hline Sardinia & $\mathrm{LWF}_{1000}$ & 0.294 & 0.077 & 0.598 & 0.180 & 0.478 & 0.215 \\
\hline
\end{tabular}


Tab. 4 - Summary of the relationship between large wildland fires (LWF) classes and days classified as high temperature days (HTD) or non-HTD, in the northern and southern part of Sardinia, from 1991 to 2009.

\begin{tabular}{|c|c|c|c|c|c|c|c|}
\hline \multirow{2}{*}{ Kind } & \multirow{2}{*}{ Description } & \multicolumn{3}{|c|}{ North } & \multicolumn{3}{|c|}{ South } \\
\hline & & $\mathbf{L W F}_{100}$ & $\mathbf{L W F}_{500}$ & $\mathbf{L W F}_{1000}$ & $\mathbf{L W F}_{100}$ & $\mathbf{L W F}_{500}$ & $\mathbf{L W F}_{1000}$ \\
\hline \multirow[t]{6}{*}{ HTD } & Number of days classified as HTD & & 36 & & & 72 & \\
\hline & HTD with LWF (\%) & 41.6 & 22.2 & 11.1 & 30.6 & 11.1 & 2.8 \\
\hline & $\begin{array}{l}\text { Normalized LWF average number per HTD } \\
\text { with LWF }\end{array}$ & $2.7 \pm 0.69$ & $2.1 \pm 0.65$ & $2.2 \pm 0.75$ & $1.6 \pm 0.21$ & $1.2 \pm 0.21$ & $0.8 \pm 0$ \\
\hline & $\begin{array}{l}\text { Normalized LWF average daily area burned } \\
\text { per HTD with LWF (ha day }{ }^{-1} \text { ) }\end{array}$ & $2503 \pm 1219$ & $4593 \pm 2325$ & $6423 \pm 3066$ & $882 \pm 295$ & $1638 \pm 715$ & $3708 \pm 1735$ \\
\hline & Average LWF size (ha) & $944 \pm 244$ & $1934 \pm 530$ & $2973 \pm 901$ & $536 \pm 153$ & $1358 \pm 513$ & $4612 \pm 2159$ \\
\hline & $\begin{array}{l}\text { LWF area burned during HTD / LWF total area } \\
\text { burned }(\%)\end{array}$ & 26.2 & 34.7 & 39.4 & 19.9 & 35.8 & 45.8 \\
\hline \multirow[t]{6}{*}{ Non-HTD } & Number of days classified as non-HTD & & 2283 & & & 2246 & \\
\hline & Non-HTD with LWF (\%) & 8.6 & 1.6 & 0.7 & 12 & 2.9 & 0.7 \\
\hline & $\begin{array}{l}\text { Normalized LWF average number per } \\
\text { non-HTD with LWF }\end{array}$ & $1.4 \pm 0.10$ & $1.2 \pm 0.09$ & $1.1 \pm 0.10$ & $1.2 \pm 0.05$ & $0.9 \pm 0.06$ & $0.80 \pm 0$ \\
\hline & $\begin{array}{l}\text { Normalized LWF average daily area burned } \\
\text { per non-HTD with LWF (ha day }{ }^{-1} \text { ) }\end{array}$ & $541 \pm 91$ & $1972 \pm 487$ & $2815 \pm 922$ & $290 \pm 23$ & $711 \pm 96$ & $1097 \pm 715$ \\
\hline & Average LWF size (ha) & $396 \pm 50$ & $1371 \pm 268$ & $2682 \pm 696$ & $243 \pm 11$ & $788 \pm 63$ & $1364 \pm 129$ \\
\hline & $\begin{array}{l}\text { LWF area burned during non-HTD / LWF total } \\
\text { area burned }(\%)\end{array}$ & 73.8 & 65.3 & 60.6 & 80.1 & 64.2 & 54.2 \\
\hline
\end{tabular}

Tab. 5 - Comparison between high temperature days (HTD) and non-HTD of the average large wildland fire (LWF) size and for those days with at least one LWF: (i) average daily number of LWF; (ii) average daily area burned per LWF for all LWF classes from 1991 to 2009. Values in parenthesis are the P statistics.

\begin{tabular}{|c|c|c|c|c|}
\hline Indicator & LWF class & $\begin{array}{l}\text { Normalized LWF average number } \\
\text { per HTD/non-HTD with LWF }\end{array}$ & $\begin{array}{c}\text { Normalized LWF average daily area } \\
\text { burned per HTD/non-HTD } \\
\text { with LWF }\end{array}$ & Average LWF size \\
\hline \multirow[t]{3}{*}{ North } & $\mathrm{LWF}_{100}$ & Significant difference $(<0.001)$ & Significant difference $(<0.001)$ & Significant difference $(0.001)$ \\
\hline & $\mathrm{LWF}_{500}$ & Significant difference $(0.029)$ & No significant difference $(0.084)$ & No significant difference $(0.312)$ \\
\hline & $\mathrm{LWF}_{1000}$ & Significant difference $(0.016)$ & No significant difference $(0.139)$ & No significant difference $(0.801)$ \\
\hline \multirow[t]{3}{*}{ South } & $\mathrm{LWF}_{100}$ & Significant difference $(0.008)$ & Significant difference $(<0.001)$ & Significant difference $(<0.001)$ \\
\hline & $\mathrm{LWF}_{500}$ & No significant difference $(0.069)$ & Significant difference $(0.023)$ & No significant difference $(0.069)$ \\
\hline & $\mathrm{LWF}_{1000}$ & No significant difference $(0.95)$ & Significant difference (0.008) & Significant difference $(0.008)$ \\
\hline
\end{tabular}

Tab. 6 - Normalized average number of fire ignitions and standard error in high temperature days (HTD) with and without large wildland fires (LWF), in north and south Sardinia, from 1991 to 2009.

\begin{tabular}{lcccc}
\hline \multicolumn{1}{c}{ Parameter } & \multicolumn{2}{c}{ North } & & South \\
\cline { 2 - 5 } & $\begin{array}{c}\text { Normalized average } \\
\text { number of fire ignitions }\end{array}$ & p-value & $\begin{array}{c}\text { Normalized number } \\
\text { of fire ignitions }\end{array}$ & p-value \\
\hline Days with $\mathrm{LWF}_{100}$ & $14.4 \pm 1.7$ & $<0.001$ & $23.0 \pm 2.0$ & $<0.001$ \\
Days without LWF & $7.0 \pm 0.6$ & & $12.8 \pm 0.7$ & $<0.001$ \\
\hline Days with $\mathrm{LWF}_{500}$ & $16.2 \pm 2.0$ & $<0.001$ & $28.4 \pm 4.0$ & \\
Days without LWF & $8.3 \pm 0.9$ & 0.011 & $41.8 \pm 7.2$ & $<0.001$ \\
\hline Days with $\mathrm{LWF}_{5000}$ & $17.1 \pm 3.7$ & & $15.2 \pm 0.8$ & \\
Days without $\mathrm{LWF}_{1000}$ & $9.2 \pm 0.9$ & & & \\
\hline
\end{tabular}

Tab. 7 - Normalized average wind speed and standard error in high temperature days (HTD) with and without large wildland fires (LWF), in north and south Sardinia, from 1991 to 2009.

\begin{tabular}{|c|c|c|c|c|c|c|c|c|}
\hline \multirow{3}{*}{ Parameter } & \multicolumn{4}{|c|}{ North } & \multicolumn{4}{|c|}{ South } \\
\hline & \multicolumn{2}{|l|}{ Alghero } & \multicolumn{2}{|l|}{ Olbia } & \multicolumn{2}{|c|}{ Capo Frasca } & \multicolumn{2}{|c|}{ Decimomannu } \\
\hline & $\begin{array}{l}\text { Normalized ave- } \\
\text { rage wind speed }\end{array}$ & p-value & $\begin{array}{l}\text { Normalized ave- } \\
\text { rage wind speed }\end{array}$ & p-value & $\begin{array}{l}\text { Normalized ave- } \\
\text { rage wind speed }\end{array}$ & p-value & $\begin{array}{l}\text { Normalized ave- } \\
\text { rage wind speed }\end{array}$ & p-value \\
\hline Days with $\mathrm{LWF}_{100}$ & $14.6 \pm 1.8$ & 0.119 & $12.7 \pm 1.7$ & 0.546 & $18.6 \pm 1.4$ & 0.700 & $14.3 \pm 1.5$ & 0.936 \\
\hline Days without $\mathrm{LWF}_{100}$ & $11.8 \pm 0.7$ & & $11.7 \pm 0.8$ & & $17.9 \pm 1.1$ & & $14.4 \pm 0.9$ & \\
\hline Days with $\mathrm{LWF}_{500}$ & $17.9 \pm 2.5$ & 0.002 & $12.7 \pm 2.8$ & 0.712 & $20.8 \pm 1.8$ & 0.270 & $15.7 \pm 2.2$ & 0.552 \\
\hline Days without $\mathrm{LWF}_{500}$ & $11.6 \pm 0.6$ & & $11.9 \pm 0.8$ & & $17.7 \pm 0.9$ & & $14.2 \pm 0.8$ & \\
\hline Days with LWF $_{1000}$ & $18.9 \pm 4.5$ & 0.015 & $9.1 \pm 0.7$ & 0.200 & $26.3 \pm 5.1$ & 0.107 & $21.0 \pm 2.3$ & 0.152 \\
\hline Days without $\mathrm{LWF}_{1000}$ & $12.3 \pm 0.8$ & & $12.5 \pm 0.9$ & & $17.8 \pm 7.2$ & & $14.2 \pm 0.8$ & \\
\hline
\end{tabular}


lar considering the weather station of Alghero. On the other hand, we did not find significant influences of wind speed on LWF in the southern part of the island (Tab. 7).

\section{Discussion}

Whereas it is accepted that the major components for fire weather forecasts are low atmospheric humidity, high temperatures, and strong winds near the ground surface (Pyne et al. 1996), meteorological indexes developed to evaluate temporal and spatial variations in meteorological conditions are not frequently used or available for all fire weather forecast agencies (Charney \& Keyser 2010, Crimmins 2006). For that reason, we highlight the significance of discerning between HTD and non-HTD defined by the $850 \mathrm{hPa}$ synoptic conditions in developing pre-suppression efforts to stand up to large fires. It would be extremely useful to be able to identify the simply "bad" and the "very bad" fire days with some reasonable lead time (i.e., 24 or 48 hours). We advise that this classification concerning HTD and nonHTD (at $850 \mathrm{hPa}$ ) can be used for that discrimination.

Some studies have established that mean, maximum and minimum temperatures have increased and will very likely increase in the next years in south Europe (Arca et al. 2012, Cane et al. 2012, IPCC 2007, Moriondo et al. 2006, Regato 2008). Giannakopoulos et al. (2009) studied possible differences between two reference periods (from 19611990 to 2031-2060) in terms of number of hot days (days with $\mathrm{T}_{\max }>30{ }^{\circ} \mathrm{C}$ on the surface) and heat-wave days $\left(\mathrm{T}_{\max }>35^{\circ} \mathrm{C}\right)$ in the Mediterranean basin: in some of these areas, like for instance central Spain or north Italy, an increase in the occurrence of hot days and heat waves is expected, with 1-3 additional weeks per year. Therefore, in Mediterranean areas, HTDs are expected to become more frequent and to determine a decrease in air humidity and fuel moisture (Moreno 2005), along with an increase in the fire behavior potential (Arca et al. 2012). Overall, in the Mediterranean basin, most HTD are related to the weather regime bringing hot dry air masses from north Africa (Pereira et al. 2011, Rodriguez-Puebla et al. 2010).

In recent years, an increase in the frequency of heat waves identified using the 850 $\mathrm{hPa}$ synoptic conditions as indicator was observed in northern Spain (Cardil et al. 2013) However, our work highlighted that the number of HTD did not change significantly from 1991 to 2009 in neither north nor south Sardinia. Furthermore, both the total normalized annual LWF number and area burned under non-HTD decreased in north and south Sardinia from 1991 to 2009 as in northern Spain (Cardil et al. 2013). In particular, the normalized annual area burned decreased significantly under non-HTD condi- tions. Nevertheless, the normalized annual burned area and number of LWF under HTD did not change in the same period. In short, fire numbers and area burned have been reduced only on days of mild weather conditions in recent years. This fact could be explained with more efficient fire control activity due to important investments in fire suppression technology and training in the last years under non-HTD (http://www.sardegnaambiente.it/protezionecivile/).

Additionally, as expected, the normalized LWF average daily number with LWF, the normalized LWF average daily area burned with LWF, the percentage of days with LWF and the average LWF size were significantly higher under HTD than non-HTD conditions. Therefore, HTD influenced the occurrence of LWF and the area burned in those days. Moreover, this work suggested that HTD are critical for both fuel managers and firefighters, although the number of HTD did not increase in the study period. Probably, fires spreading under HTD can propagate faster and more intensely due to the low dead fuel moisture content and the water stress for live fuels.

Besides, this study shows that HTD with LWF had a higher number of ignitions than HTD without LWF. This could determinate a collapse in the efficiency of the fire suppression system during extreme weather conditions. Moreover, some fires remained smaller than 100 ha due to the quick and effective efforts of the firefighting forces. This is to say, some fires might have not grown larger in recent years because of a larger suppression power, in particular in non-HTD conditions.

Our work also highlighted relevant differences between north and south Sardinia regarding the relationship between fires and HTD. In the northern part of the island, the average frequency of HTD was lower than in the south (1.84 vs. 3.73 HTD per year, respectively), but the incidence of large fires burning in those days was clearly larger in terms of LWF area burned, number and size, particularly as far as $\mathrm{LWF}_{500}$ and $\mathrm{LWF}_{1000}$ were concerned. This result suggested that the susceptibility to suffer large fires in the north of the island is higher than in the south, and that the use of $850 \mathrm{hPa}$ synoptic conditions needs a careful evaluation and analysis to take into account other local phenomena (influence of topography, continentality effects, local winds, fuel types, etc.). From this point of view, for instance, wind speed was identified as a key factor to affect the occurrence of $\mathrm{LWF}_{500}$ and $\mathrm{LWF}_{1000} \mathrm{du}-$ ring HTD in northern Sardinia.

In recent years, most of the largest wildfires in Sardinia happened in extreme HTD, as in 2007, 2009 or 2012 (Salis et al. 2012b). This supports the statement that HTD provides more extreme conditions for fire propagation and more difficulties to suppress those fires. This also occurred in other countries (Mills 2005, Trigo et al. 2006, Barriopedro et al. 2011, Pereira et al. 2011, CNFDB 2013) for the severe wildfires that affected Portugal (2003, 2005), Greece (2007), Spain (1994, 2006, 2009), Russia (2010), USA (2000, 2006 and 2007), Canada (2004), Australia (2005, 2006, 2009, 2011, 2012).

Using fine-scale simulation modeling on weather scenarios historically associated with large fires (i.e., heat waves and strong winds) could help fire managers to be more effective in addressing fire management in the Mediterranean basin, and to identify the priority areas in terms of extreme fire intensity or exposure of values of interest and assets (Farris et al. 2000, Ager \& Finney 2009, Salis et al. 2012a, Thompson et al. 2012a). It also allows for developing efficient methods and guidelines in a perspective of fire risk mitigation and budgetary planning (Ager et al. 2011, Thompson et al. 2012b).

We are aware that in the future an important effort could be done in order to refine the division of the island in more pyro-climatic areas. Nonetheless, this study represents an important base for further investigations, and is so far the first study covering the complex relationship among temperatures at $850 \mathrm{hPa}$, large fires, and weather conditions in an Italian fire-prone area.

\section{Conclusions}

Results showed that neither the number of fires nor the area burned decreased under high temperature days (HTD), although a decrease of both indicators was observed on other days. Furthermore, the number of HTD did not significantly increase from 1991 to 2009 in Sardinia. However, we found a clear relationship between HTD and both LWF occurrence and LWF area burned.

Predicting HTD with reasonable lead time is critical for both fuel managers and firefighters to implement more efficient fire suppression tactics and strategies. The classification of HTD and non-HTD (at $850 \mathrm{hPa}$ ) could be used for discriminating those days in order to optimize fire control activities and the available firefighting resources.

Despite the increased amount of money invested in suppression resources in the period analyzed, the total normalized annual area burned by LWF under HTD did not decrease in either northern or southern Sardinia. Additionally, the normalized LWF average daily area burned, the normalized LWF average daily number, the percentage of days with LWF and the average LWF size were significantly higher under HTD than nonHTD conditions. Therefore, HTD conditions may be a useful indicator of an increased probability of the occurrence of severe wildland fires. 


\section{Acknowledgments}

We are thankful to the Spanish Ministry of Economy and Competitiveness (ForBurn Ref: AGL2012-40098-CO3-01) for supporting this study. We are appreciative to the University of Lleida and Pau Costa Foundation for supporting this study through a partial grant to fund Adrian Cardil PhD studies. We are also grateful to the GEMINA Project (MIUR/MATTM number 232/2011) and the EXTREME Project (L.R. 7-2007, CRP$25405)$ for supporting this work. We appreciate the Corpo Forestale e di Vigilanza Ambientale della Regione Sardegna for providing the wildland fire dataset.

\section{References}

Ager AA, Finney M (2009). Application of wildfire simulation models for risk analysis. Geophysical Research Abstracts 11: EGU2009-5489. Ager AA, Vaillant N, Finney MA (2011). Application of fire behavior models and geographic information systems for wildfire risk assessment and fuel management planning. Journal of Combustion 2011: 572452 . - doi: 10.1155/2011/572 452

Arca B, Duce P, Laconi M, Pellizzaro G, Salis M, Spano D (2007). Evaluation of FARSITE simulator in Mediterranean maquis. International Journal of Wildland Fire 16: 563-572. - doi: 10.1071/WF06070

Arca B, Pellizzaro G, Duce P, Salis M, Bacciu V, Spano D, Ager A, Finney M, Scoccimarro E (2012). Potential changes in fire probability and severity under climate change scenarios in Mediterranean areas. In: "Modelling Fire Behaviour and Risk" (Spano D, Bacciu V, Salis M, Sirca C eds). NuovaStampacolor, Sassari, Italy, pp. 9298.

Barriopedro D, Fischer EM, Luterbacher J, Trigo RM, García-Herrera R (2011). The hot summer of 2010: redrawing the temperature record map of Europe. Science 332: 220-224. - doi: 10.1126/ science. 1201224

Cardil A, Molina DM, Ramirez J, Vega-García C (2013). Trends in adverse weather patterns and large wildland fires in Aragon (NE Spain) from 1978 to 2010. Natural Hazards and Earth System Science 13: 1393-1399. - doi: 10.5194/nhess-131393-2013

Charney JJ, Keyser D (2010). Mesoscale model simulation of the meteorological conditions during the 2 June 2002 Double Trouble State Park wildfire. International Journal of Wildland Fire 19: 427-448. - doi: 10.1071/WF08191

CNFDB (2013). Canadian National Fire Database. Web site. [online] URL: http://cwfis.cfs.nrcan.gc.ca/en_CA/nfdb/poly.html

Cane D, Barbarino S, Renier L, Ronchi C (2012). Detailed downscaling through ensemble techniques of the regional climate models for a fire weather indices projection in the Alpine region. In: "Modelling Fire Behaviour and Risk" (Spano D, Bacciu V, Salis M, Sirca C eds). NuovaStampacolor, Sassari, Italy, pp. 85-91.

Crimmins MA (2006). Synoptic climatology of extreme fire-weather conditions across the southwest United States. International Journal of Climatology 26: 1001-1016. - doi: 10.1002/joc.13 00

Chessa PA, Delitala A (1997). Il clima della Sardegna. In: "Collana Note Tecniche di Agrometeorologia per la Sardegna”. (Milella A ed). Sassari, Italy, pp. 17-38. [in Italian]

De Angelis A, Ricotta C, Bajocco S (2012). Phenological variability drives the distribution of wildfires in Sardinia. Landscape Ecology 27: 1535-1545. - doi: 10.1007/s10980-012-9808-2

Farris CA, Pezeshk C, Neuenschwander LF (2000). A comparaison of fire probability maps derived from GIS modeling and direct simulation technique. In: Proceedings the Joint Fire Science Conference and Workshop "Crossing the Millennium: Integrating Spatial Technologies and Ecological Principles for a New Age in Fire Management" (Neuenschwander LF, Ryan KC, Gollberg GE, Greer JD eds). Boise (Idaho - USA), 15-17 June 1999. University of Idaho, Moscow, ID, USA, pp. 130-137.

García-Herrera R, Díaz J, Trigo RM, Hernández E (2005). Extreme summer temperatures in Iberia: health impacts and associated synoptic conditions. Annales Geophysicae 23: 239-251. - doi: 10.5194/angeo-23-239-2005

García-Ortega E, Trobajo MT, López L, Sánchez JL (2011). Synoptic patterns associated with wildfires caused by lightning in Castile and Leon, Spain. Natural Hazards and Earth System Science 11: 851-863. - doi: 10.5194/nhess-11-85 1-2011

Flannigan MD, Stocks BJ, Wotton BM (2000). Climate change and forest fires. Science of the Total Environment 262: 221-229. - doi: 10.1016/ S0048-9697(00)00524-6

Ganteaume A, Jappiot M (2012). What causes large fires in southern France. Forest Ecology and Management 294: 76-85. - doi: 10.1016/j.for eco.2012.06.055

Giannakopoulos C, Le Sager P, Bindi M, Moriondo M, Kostopoulou, E, Goodess CM (2009). Climatic changes and associated impacts in the Mediterranean resulting from a $2{ }^{\circ} \mathrm{C}$ global warming. Global Planet Change 68: 209-224. doi: 10.1016/j.gloplacha.2009.06.001

IPCC (2007). IPCC Fourth Assessment Report: Climatic Change 2007. [online] URL: http://www.ipcc.ch/ipccreports/assessments-reports.htm

Kalnay E, Kanamitsu M, Kistler R, Collins W, Deaven D, Gandin L, Iredell M, Saha S, White G, Woollen J, Zhu Y, Chelliah M, Ebisuzaki W, Higgins W, Janowiak J, Mo KJ, Ropelewski C, Wang J, Leetmaa A, Reynolds R, Jenne R, Joseph D (1996). The NCEP/NCAR 40-year reanalysis project. Bulletin of the American Meteorology Society 77: 437-471. - doi: 10.1175/ 1520-0477(1996)077<0437:TNYRP >2.0.CO;2

Kuglitsch FG, Toreti A, Xoplaki E, Della-Marta PM, Zerefos CS, Türkes M, Luterbacher J (2010). Heat wave changes in the eastern Mediterranean since 1960. Geophysical Research Letters 37: L04802. - doi: 10.1029/2009GL041841
Mills GA (2005). A re-examination of the synoptic and mesoscale meteorology of Ash Wednesday 1983. Australian Meteorological Magazine 54: $35-55$.

Molina DM, Castellnou M, Garcia-Marco D, Salgueiro A (2010). Improving fire management success through fire behaviour specialists. Research Report 23, European Forest Institute, Joensuu, Finland, pp. 105-119.

Montserrat D (1998). Situaciones sinópticas relacionadas con el inicio de grandes incendios forestales en Cataluña. NIMBUS 1-2: 93-112. [in Spanish]

Moreno JM (2005). Impactos sobre los riesgos naturales. Riesgo de incendios forestales. In: "Evaluación preliminar de los impactos en España por Efecto del Cambio climático". Spanish Ministry of Environment, Madrid, Spain, pp. 581-615. [in Spanish]

Moriondo M, Good P, Durao R, Bindi M, Giannakopoulos C, Corte-Real J (2006). Potential impact of climate change on fire risk in the Mediterranean area. Climate Research 31: 85-95. doi: $10.3354 / \mathrm{cr} 031085$

Ogi M, Yamazaki K, Tachibana Y (2005). The summer Northern annular mode and abnormal summer weather in 2003. Geophysical Research Letters 32: L04706.

Pereira MG, Malamud BD, Trigo RM, Alves PJ (2011). The history and characteristics of the 1980-2005 Portuguese rural fire database. Natural Hazards and Earth System Science 11: 33433358. - doi: 10.5194/nhess-11-3343-2011

Pyne SJ, Andrews P, Laven RD (1996). Introduction to wildland fire $\left(2^{\text {nd }} e d n\right)$. John Wiley and Sons, New York, USA, pp. 769.

Regato P (2008). Adapting to global change: Mediterranean forests. IUCN Centre for Mediterranean Cooperation, Malaga, Spain, pp. 254.

Riaño D, Ruiz JA, Isidoro D, Ustin SL (2007). Global spatial patterns and temporal trends of burned area between 1981 and 2000 using NOAA-NASA Pathfinder. Global Change Biology 13: 40-50. - doi: 10.1111/j.1365-2486.20 06.01268.x

Ricotta C, Guglietta D, Migliozzi A (2012). No evidence of increased fire risk due to agricultural land abandonment in Sardinia (Italy). Natural Hazards and Earth System Science 12: 13331336. - doi: 10.5194/nhess-12-1333-2012

Rodriguez-Puebla C, Encinas AH, García-Casado LA, Nieto S (2010). Trends in warm days and cold nights over the Iberian Peninsula: relationships to large-scale variables. Climatic Change 100: 667-684. - doi: 10.1007/s10584-009-97210

Salis M, Ager AA, Arca B, Finney MA, Bacciu V, Duce P, Spano D (2012a). Assessing exposure of human and ecological values to wildfire in Sardinia, Italy. International Journal of Wildland Fire. - doi: 10.1071/WF11060

Salis M, Mavuli S, Falchi S, Piga A, Desole G, Montesu GP, Spano D (2012b). Extreme wildfire spread and behavior: a case study from North Sardinia. In: "Modelling Fire Behaviour and Risk” (Spano D, Bacciu V, Salis M, Sirca C 
eds). NuovaStampacolor, Sassari, Italy, pp. 138144.

Stocks BJ, Mason JA, Todd JB, Bosch EM, Wotton BM, Amiro BD, Flanningan MD, Hirsch KG, Logan KA, Martell DL, Skinner WR (2003). Large forest fires in Canada, 1959-1997. J Geophys Res Atmos 108: 5-12.

Thompson MP, Ager AA, Finney MA, Calkin DE, Vaillant NM (2012a). The science and opportu- nity of wildfire risk assessment (chapt. 6). In: "Novel Approaches and Their Applications in Risk Assessment” (Luo Y ed). Intech, Shangai, China, pp. 99-120.

Thompson MP, Calkin DE, Finney MA, Gebert KM, Hand MS (2012b). A risk-based approach to wildland fire budgetary planning. Forest Science 59: 63-77. - doi: 10.5849/forsci.09-124

Trigo RM, García-Herrera R, Díaz J, Trigo IF,
Valente MA (2005). How exceptional was the early August 2003 heatwave in France? Geophysical Research Letters 32: L10701.

Trigo RM, Pereira JM, Mota B, Calado T, Dacamara C, Santo F (2006). Atmospheric conditions associated with the exceptional fire season of 2003 in Portugal. International Journal of Climatology 26: 1741-1757 - doi: 10.1002/joc.1333 